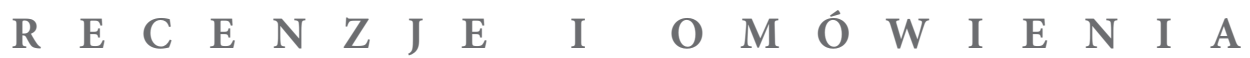

Wieś i Rolnictwo 1 (170)/2016

ISSN 0137-1673

doi: 10.7366/wir012016/10

Maria Wieruszewska

\title{
Recenzja książki Wojciecha Goszczyńskiego, Wojciecha Kniecia, Huberta Czachowskiego: Lokalne horyzonty zdarzeń ${ }^{1}$
}

\begin{abstract}
A Review of a Book by Wojciech Goszczyński, Wojciech Knieć, Hubert Czachowski: Lokalne horyzonty zdarzeń
\end{abstract}

Na okładce książki widnieje grafika, która przedstawia poskręcane kłącza wymowny znak tego, co autorzy nazwali „skomplikowanym splotem lokalności”. W liście dołączonym do książki - prezentu czytam, że ma ona pobudzić dyskusję nad Polską lokalną, perspektywami samorządności i poszukiwaniem „,efektywnego modelu jej rozwoju”. Korzystam więc z zaproszenia do namysłu i przystępuję do dzielenia się refleksją wedle własnego klucza. Zacznę od tego, co najciekawsze, a więc zauważonej przeze mnie odmienności rezultatów badań na tle innych, znanych ustaleń, które wyraźnie dominują w dyskursie na temat wsi. Następnie przejdę do dyskusji z autorami recenzowanej książki. Na koniec odszukam pola styczne pomiędzy stanowiskami prezentowanymi w książce a tym, co uważam za podstawowe w dyskusji nad Polską lokalną.

Przede wszystkim należy zwrócić uwagę, że wyniki badań zrywają z myślowymi kliszami na temat słabego kapitału społecznego. Nie potwierdzają się stereotypowe oceny, które są powielane w literaturze jako uproszczony efekt przyjęcia jednostronnych kryteriów (s. 127). Badania wsi kujawsko-pomorskiej uznają wprawdzie niską efektywność działań wpisanych w III sektor, co oczywiście zaniża poziom swoiście pojmowanego kapitału społecznego, ale to wcale nie uprawnia do uogólnionego twierdzenia o niskim kapitale społecznym w społecznościach wiejskich. Z drugiej

Autorka jest pracownikiem naukowym Instytutu Rozwoju Wsi i Rolnictwa PAN (e-mail: mwierusz@ irwirpan.waw.pl).

1 W. Goszczyński, W. Knieć, H. Czachowski, Lokalne horyzonty zdarzeń. Lokalność i kapitat społeczny w kulturze (nie)ufności na przykładzie wsi kujawsko-pomorskiej, Muzeum Etnograficzne im. Marii Znamierowskiej-Prüfferowej w Toruniu, Toruń 2015. 
strony wyniki ukazują, jak „badane społeczności nieźle radzą sobie na poziomie działań nieformalnych" (s. 132). Problemem zatem jest niedostosowanie modelu działania tego sektora do cech lokalnej kultury (s. 197). Z tym łączy się zagrożenie, jakim jest „przepaść pomiędzy polityką państwa, jego instytucjami, makroekonomicznymi wskaźnikami rozwoju a mieszkańcami” (s. 109). Kolejna konstatacja, wprawdzie nie nowa, ale jakby zapomniana, dotyczy fundamentalnej prawdy, iż „nawet najlepszy pomysł, program rozwoju, jeżeli zostanie wprowadzony z zewnątrz [podkr. M.W.], to będzie trafiał na mur braku zaufania mieszkańców” (s. 194)². W tym miejscu pozwolę sobie na dygresję. To samo miał na myśli Jędrzej Cierniak, przedwojenny inteligent z Zaborowa - ówczesny kurator oświaty pozaszkolnej, gdy pisał: „pozwólcie wsi być sobą, bo to bodaj czy nie największa jej siła twórcza” (Wieruszewska 1997, s. 122). W innym miejscu dodawał: „w każdym środowisku nawet te same działania znajdują swój odrębny, niepowtarzalny oddźwięk" (Wieruszewska 1992, s. 171). Helena Radlińska - pedagog społeczny - przestrzegała przed importowanymi z zewnątrz pomysłami na zmianę w społeczności wiejskiej, ponieważ o ile nie zostaną przez ludzi uznane za swoje, są z reguły skazane na niepowodzenie. Zdawałoby się, że to nic odkrywczego, mówiąc żartobliwie - oczywista oczywistość. Trzeba wobec tego zadać pytanie: dlaczego te i inne przestrogi przed, mówiąc najogólniej, niepożądanymi skutkami „beztroskiego zakupu licencji rozwojowej" (Stacewicz 1992) przy równoczesnym ignorowaniu wiedzy i doświadczenia samych mieszkańców wsi, ale także wobec dystansu przy podejmowaniu prób przełamania nieadekwatnych do wymogów czasu paradygmatów rozwoju, jakoś nie przemawiały - jak dotąd - do pomysłodawców zarządzania zmianą społeczną na wsi? Odpowiedź wykracza poza ramy tej skromnej recenzji. Chciałoby się rzec „mądry Polak po szkodzie”, szczególnie gdy na tle lektury recenzowanej pracy powracam do myśli zawartych w książce Odnowa wsi. Między mitem a nadzieja (Wieruszewska 1992) ${ }^{3}$. To tłumaczy sytuację, wcale nie wyjątkową, interpretowaną przez autorów jako ryzyko i zagrożenie, że instytucje o charakterze ponadlokalnym są przez społeczności wiejskie odbierane jako niezrozumiałe „bądź funkcjonujące tylko i wyłącznie we własnym interesie" (s. 109).

Rozmaite koncepcje rozwoju oparte na relacjach i „przepływach lokalnych z pozalokalnymi” $\mathrm{w}$ świetle wspomnianych okoliczności każą postawić pytanie o skuteczność i sensowność eksploatowanych szeroko koncepcji teoretycznych. Na

2 Te same prawdy za sprawą Jędrzeja Cierniaka, Heleny Radlińskiej, Kazimiery Zawistowicz-Adamskiej stanowiły w okresie II Rzeczypospolitej przesłanie adresowane do ówczesnych działaczy podejmujących prace w społecznościach wiejskich.

3 W książce wydanej w roku 1992 przez IRWiR PAN pod moją redakcją znalazły się, poza ważnym i dzisiaj wstępem, zakończeniem oraz autorskim rozdziałem, teksty: Andrzeja Kalety, Eugenii Jagielło-Łysiowej, Jana Szczepańskiego, Franciszka Jakubczaka, Barbary Fedyszak-Radziejowskiej i Izabelli Bukraby-Rylskiej. 
tym tle nieoczywiste są koncepty tak zwanego rozwoju neoendogennego, partnerstw terytorialnych, branżowych, wielosektorowych. Skoro sieci ponadlokalne są słabe, a „treści i symbole przez nie przesyłane działają na niekorzyść [podkr. M.W.] społeczności” (s. 115), to istotnie mamy do czynienia z działaniami pozornymi, na dodatek przy użyciu niewłaściwych narzędzi. Stąd wołanie autorów o „podjęcie ryzyka i przekazanie większej liczby uprawnień samym społecznościom” (s. 197), jako swoisty rewers błędnych, choć nagminnych praktyk, w których głównym motywem powstania organizacji pozarządowej lub partnerstwa są jedynie dostępne środki finansowe. Można pogratulować autorom wnikliwości, gdy dzielą się z czytelnikami podejrzeniem: „czy samorządy celowo nie utrudniają włączania się mieszkańców w proces podejmowania decyzji” (s. 195)? Odchodząc od podejrzeń o intencje spiskowe, jest coś na rzeczy, skoro na podstawie innych badań uwzględni się lepszą współpracę i zgodność działań pomiędzy władzą lokalną, organizacjami pozarządowymi a napływającymi na tereny wiejskie nowymi osadnikami z miast niż - o paradoksie - z rolniczymi, rdzennymi mieszkańcami wsi.

Pożądana zmiana w tym zakresie wymaga głębszego namysłu nad lokalną tożsamością kulturową i koniecznością docenienia - oby nie za późno - czegoś na kształt kulturowych kotwic, by posłużyć się terminem autorstwa Tomasza Szlendaka. Nawet jeśli poszukiwania takie - $\mathrm{w}$ istocie trudne i wymagające szczególnych kompetencji - niektórych drażnią swoim populizmem i hybrydową formą, to dla autorów recenzowanej pracy, którzy spoglądają na badane społeczności jakby przez dziecięcy kalejdoskop, istotny jest sam proces powstawania nowych, unikalnych struktur, ważniejszy aniżeli ich kształt (s. 34). Deklaracja powyższa sugeruje, iż bardziej niż trwanie zajmuje ich stawanie się (in statu nascendi). Skoro tak, to akcent kładziony na proces nie powinien abstrahować od takich jego wymiarów, jak: długotrwałość, żywiołowość lub celowość (planowanie). Autorzy expressis verbis deklarują, że nie są „Zwolennikami wizji samoregulujących się wspólnot” (s. 132). Trudno stwierdzić, czy odrzucona przez nich wizja odnosi się do samoregulacji, inaczej samoczynności procesu, czy obejmuje także kategorię wspólnoty. Nie rozwijam tego wątku. Chciałabym jednak zwrócić uwagę na obecny w socjologii pejoratywny wydźwięk i negatywne pojmowanie procesów samoczynnych. Są przesłanki, aby sądzić, iż autorom nie udało się wyzwolić od oceniającego, bo nie chcę powiedzieć, że ideologicznego wymiaru procesu. Rozwinięcie tej argumentacji, którą tylko sygnalizuję, odsyła do szerszego omówienia procesów żywiołowych (Kwaśniewicz 2002, s. 214).

Na uwagę zasługuje polemika autorów dotycząca wagi instytucjonalizacji dla stymulowania aktywności. Okazuje się, że zdolność do działań wspólnych nie zawsze jest skorelowana $\mathrm{z}$ wysokimi wskaźnikami instytucjonalizacji. Odwrotnie, zdarza się, że zakorzenione wspólnoty o silnych nieformalnych więziach sprzyjają 
wspólnym działaniom, poszukując „zasobów, pomysłów na rozwój w obrębie ograniczonej fizycznie przestrzeni” (s. 100). Co warte zauważenia, konstatacja autorów na temat negatywnego w skutkach „rażenia miejskością” (s. 113), w rezultacie napływu nowych osadników, nie potwierdza popularnej tezy o pozytywnym wpływie ludności napływowej na „rozszerzenie społecznego horyzontu lokalności”. Analogicznie rezerwę badaczy budzi zakorzenione przekonanie o większej aktywności młodego pokolenia. Okazuje się, że jest to grupa, „która nie różni się jakościowo od osób dorosłych" (s. 129). Inny przełamany stereotyp dotyczy rolników, którzy „dobrze wypadają na tle całej populacji”, charakteryzują się bowiem wyższą niż inne grupy - na przykład przedsiębiorcy - aktywnością, a „ich związki ze społecznością mają bardziej dynamiczny charakter" (s. 104). Wobec tej konstatacji warto zapytać czy myślowe klisze w rodzaju tej, że ponieważ „pojęcie «Wieś» tradycyjnie kojarzy się z pojęciem "rolnictwo»", to tym samym uprawnia do twierdzenia, iż aktualnie jest „to skojarzenie stereotypowe”? (Halamska 2015, s. 54). Mam w tej kwestii inne zdanie ${ }^{4}$. W moim przekonaniu upada kolejne założenie dotyczące zarządzania zmianą $\mathrm{w}$ społecznościach, ufundowane na przekonaniu o stymulujących rozwój relacjach ponadlokalnych.

Powyższe wątki uznałam za oryginalne $w$ tym sensie, że nie powielają utartych przekonań i chociaż nie tworzą w książce zwartego ciągu narracji, to w mojej optyce tak właśnie dadzą się odczytać. Zasługują przy tym na pogłębienie, choć sami autorzy nie ułatwiają tego zadania, co więcej, nieraz wprawiają czytelnika w zakłopotanie, prezentując tu i ówdzie swoje credo, moim zdaniem sprzeczne z poczynionymi wcześniej uwagami.

Niespójność w linii argumentacji można przypisać temu, ze książka jest dziełem trzech autorów z różnych dyscyplin - etnologa, socjologa wsi, socjologa kultury. $\mathrm{Na}$ dodatek, co jest w tym przypadku wyzwaniem, łączy badania ilościowe z jakościowymi. Mam wrażenie, że poręczna metafora „skomplikowanego splotu” poniekąd wyręcza autorów z wysiłku jego rozsupłania. Tu słowo komentarza - badacz ma prawo do własnego ujęcia tematu i jasnego wyłożenia swojego stanowiska, czemu autorzy starają się sprostać, ale to pociąga za sobą konsekwencję w argumentowaniu, a tej mi w pracy zabrakło. By nie być gołosłowną, przejdę do zapowiedzianej polemiki z autorami. Razi mnie - etnografa - termin „społeczność klanowa” użyty jako rodzaj epitetu, bo interpretowany jako: zamknięcie, ogrodzenie, izolacja,

4 Jeśli uznać stereotyp za wyraz uproszczonego przekonania przy braku świadomości tego uproszczenia, na dodatek bez uwzględnienia specyfiki konkretnych sytuacji i przy ignorowaniu informacji, które tego przekonania nie potwierdzają. Do takich utrwalonych przekonań należy założenie dezagraryzacji jako miernik rozwoju społeczno-gospodarczego (zob. Rosner 2015, s. 27). Wprawdzie „jest jednak kilka krajów, gdzie udział rolników w strukturze pracujących nieznacznie rośnie” (Halamska 2015, s. 60), ale nie zmienia to przyjętej reprezentacji poznawczej. 
hermetyczność (s. 87), co ogranicza dostępność do zasobów i „działa na niekorzyść analizowanych społeczności”. Tak zwane „klanowe jądro” (s. 126), „klanowa społeczność" (s. 53), „klany rodzinne” (s. 172), „gorset lokalnych klanów” (s. 177) mają powodować nieefektywność, gdy tymczasem tak nie jest i tak być nie musi ani teoretycznie, ani empirycznie. Przypomina mi się uwaga Piotra Nowaka, „że wiele funkcji, które w społeczeństwach zachodnich kapitalistycznych spełniają organizacje pozarządowe, u nas spełnia rodzina $\mathrm{w}$ tradycyjnym rozumieniu" (Adamski i in. 2007, s. 175). Skąd więc ta pewność co działa na korzyść lub niekorzyść? By móc o tym wyrokować, należałoby poznać ramy aksjologiczne tych ocen lub wymogi systemowe, które przyjmuje się za pożądane, bo te czyniłyby wyrażane oceny prawdziwie wiarygodnymi. Wyniki badań - zwłaszcza w ich części jakościowej, w której zwraca się uwagę na komponenty zakorzenienia, także geograficznego, cechy wspólnoty, tożsamości, tak zwanej „autonomii mikro” (s. 43), czy też te, w których podkreśla się wagę kultury, tego nie potwierdzają. Przesłanie autorów, nawiązując do ostatniego wymiaru - „kultury (nie)ufności” - tak właśnie odczytuję. Potwierdzają to słowa: „bez wyraźnego wstrząsu, nie jest możliwe odwrócenie $[\ldots]$ ciągłej rekonstrukcji procesów odrywania jednostki od społeczności, przestrzeni fizycznej, lokalnych symboli i wartości” (s. 187). Na tym tle głębszego namysłu wymaga przytaczanie, za ustaleniami podręcznikowymi na temat dobrego rządzenia, a raczej potrzeby współzarządzania, takich kategorii jak: „lokalne kliki”, "grupy klientelistyczne, kolesiowskie” czy „amoralne klany rodzinne” (s. 48). Cenna uwaga Edmunda Wnuka-Lipińskiego na temat deficytu „instytucji zapośredniczenia interesów jednostki, jej rodziny, sąsiadów itp. wobec sektora publicznego" (s. 48) wymagałaby rozwinięcia i zapewne uchroniłaby narrację przed poplątaniem dyskursywnych wątków. Oto bowiem z jednej strony przywoływane jest klasyczne studium społeczności lokalnych Conrada M. Arensberga i Solona T. Kimballa, w którym zwraca się uwagę na rangę nieformalnej współpracy ważnej dla trwania wspólnoty i budowania zaufania. $Z$ drugiej zaś przytacza się określenia na temat ,amoralnego familizmu”, jakby odcinając się od konstytutywnych dla wsi polskiej, w jej długim trwaniu, rodzin składających się na społeczność. Kiedy pada termin społeczność, od razu nasuwa mi się metafora, z jaką zetknęłam się przy powtórnej monografii Zaborowa, referując kierunki i założenia metodologiczne badań społeczności lokalnych (Wieruszewska-Adamczyk 1980). Rozmaite ujęcia społeczności trafnie oddawało powiedzenie, iż próba określenia społeczności przypomina czerpanie galarety rękami, kiedy udaje się ją wprawdzie zatrzymać w dłoni, ale zawsze jakaś część wysunie się między palcami. Autorzy też posługują się kategorią społeczności, choć znacznie częściej społeczności z przymiotnikiem lokalna, wywodząc ją z tradycji nauk społecznych. Sami zdecydowanie kierują się w stronę „dynamicznego modelu lokalności”. Zauważają, że po „latach zastoju” 
(s. 21) lokalność stała się przedmiotem zainteresowania i kontrowersji. Nie wnikając w subtelności sporów na ten temat, autorzy stawiają sobie pytanie: „jak projektować polityki rozwoju lokalności” (s. 21)?

Chciałabym w tym miejscu podzielić się spostrzeżeniem dotyczącym swoistej ewolucji pojęcia, które w socjologii wsi najpierw zajmowała „wiejska społeczność lokalna”, stopniowo redukowana do „społeczności lokalnej”, a ostatnio - co znajduje wyraz w recenzowanej książce - do „lokalności” i „lokalnych horyzontów zdarzeń”. W warstwie poznawczej nikną wymiary wsi, „wypłukiwana” jest semantyczna warstwa społeczności, jako okrojone residuum pozostaje zaś sama lokalność. To komentarz z perspektywy teoretycznej, choć nie można zapomnieć, że w sensie empirycznym badacze gromadzili materiał jednak na wsi, dodam, kujawsko-pomorskiej. Czy zatem odejście od wizji społeczności jako samoregulującej się funkcjonalnie małej ojczyzny rzeczywiście rozszerza horyzont poznawczy? Nie jestem tego pewna, co więcej, sami autorzy zasiewają w tym względzie wątpliwość, gdy piszą: „społeczności, którym się udało" pokazują ,jak ważna jest lokalna tożsamość” (s. 192). Zgadzam się z ich przesłaniem kultura najpierw. Ważna jest kotwica kulturowa, która bazuje na tradycji, „specyfice, wyjątkowości, przestrzeni geograficznej”, to ona bowiem ma szanse, „czerpiąc z kulturowej tożsamości regionu” - jak mówią autorzy - ożywić lokalność. Czy te wizje mogą się urzeczywistnić, kiedy z pola widzenia projektantów zmian zanika wieś, gdy „następuje powolny proces dogasania, śmierci społeczności” (s. 194)? Czy są szanse, by nie ulegać nowym złudzeniom, skoro zakres semantyczny społeczności, także w optyce badań, doznaje skutków swoistego eluwium? Te pytania adresuję do czytelników tej ważnej książki.

\section{Bibliografia}

Adamski T., Dzwonkowska K., Gorlach K., Pilichowski A., Starosta P. (2007). Wiedza w rozwoju zrównoważonym. Programy - projekty - działania. Kraków: Wydawnictwo Uniwersytetu Jagiellońskiego.

Halamska M. (2015). Zróżnicowanie społeczne „wiejskiej Europy”. Wieśi Rolnictwo, 4 (169), 47-65.

Kwaśniewicz W. (2002). Procesy żywiołowe. W: Encyklopedia socjologii, t. 3. Warszawa: Oficyna Naukowa.

Rosner A. (2015). Problem pomiaru poziomu rozwoju społeczno-gospodarczego. Skala pomiarowa i jej Właściwości. Wieś i Rolnictwo, 4 (169), 11-31.

Stacewicz J. (1992). Ekonomia a kryzys nowożytnego ideału nauki. Wieś $i$ Rolnictwo, 3-4 (76-77).

Wieruszewska M. (1997). Wieś polska. Konteksty, kontrasty, strategie. Warszawa: Instytut Rozwoju Wsi i Rolnictwa PAN. 
Recenzja książki Wojciecha Goszczyńskiego, Wojciecha Kniecia, Huberta Czachowskiego...

Wieruszewska M. (red.) (1992). Odnowa wsi. Między mitem a nadzieją. Warszawa: Instytut Rozwoju Wsi i Rolnictwa PAN.

Wieruszewska-Adamczyk M. (1980). Społeczność wiejska Zaborowa w procesie przemian. Warszawa: Instytut Rozwoju Wsi i Rolnictwa PAN. 